\title{
Synthesis and Antimicrobial Resistant Modulatory Activity of 2,4-Dinitrophenylhydrazone Derivatives as Agents against Some ESKAPE Human Pathogens
}

\author{
Alberta Ade, ${ }^{1}$ Cedric D. K. Amengor $\mathbb{D}^{2},{ }^{2}$ Abena Brobbey $\left(D^{1},{ }^{1}\right.$ Isaac Ayensu, ${ }^{1}$ \\ Benjamin K. Harley, ${ }^{3}$ and Yaw Duah Boakye ${ }^{4}$ \\ ${ }^{1}$ Department of Pharmaceutical Chemistry, Faculty of Pharmacy and Pharmaceutical Sciences, \\ Kwame Nkrumah University of Science and Technology, Kumasi, Ghana \\ ${ }^{2}$ Department of Pharmaceutical Chemistry, School of Pharmacy, University of Health and Allied Sciences, Ho, Ghana \\ ${ }^{3}$ Department of Pharmacognosy and Herbal Medicine, School of Pharmacy, University of Health and Allied Sciences, Ho, Ghana \\ ${ }^{4}$ Department of Pharmaceutics, Faculty of Pharmacy and Pharmaceutical Sciences, \\ Kwame Nkrumah University of Science and Technology, Kumasi, Ghana \\ Correspondence should be addressed to Abena Brobbey; abena23@yahoo.com
}

Received 27 July 2020; Accepted 21 August 2020; Published 7 October 2020

Academic Editor: Pedro M. Mancini

Copyright (C) 2020 Alberta Ade et al. This is an open access article distributed under the Creative Commons Attribution License, which permits unrestricted use, distribution, and reproduction in any medium, provided the original work is properly cited.

\begin{abstract}
A library of six novel phenylhydrazones were synthesized and evaluated for their in vitro antimicrobial and resistance modulating activity against a panel of Gram-positive, Gram-negative, and fungal species. The compounds were produced in good yields of $60-92 \% \mathrm{w} / \mathrm{w}$ and characterized using melting point, UV-visible spectroscopy, infrared, and nuclear magnetic resonance $\left({ }^{1} \mathrm{H},{ }^{13} \mathrm{C}\right.$, and DEPT-Q) techniques. Mass spectroscopy was used to confirm the identity of one of the most active compounds, 5 [SA5]. The phenylhydrazones showed activity against all the six selected microorganisms with minimum inhibitory concentration (MIC) values of the most active compounds, 1 [BP1] and 5 [SA5], at $138 \mu \mathrm{M}$ (Klebsiella pneumoniae) and $165 \mu \mathrm{M}$ (Streptococcus pneumoniae), respectively. Compound 1 [BP1] further demonstrated a high resistance modulatory activity at $1.078 \mu \mathrm{M}$ against Streptococcus pneumoniae and Klebsiella pneumoniae.
\end{abstract}

\section{Introduction}

The world in recent decades is running out of effective antibiotics due to the increased prevalence of multidrug resistant organisms [1]. This has led to an increase in resistant infections requiring scientists to relentlessly explore the possibility of synthesizing analogues of active or lead compounds as novel antimicrobials to curb these infections and resultant diseases. Infectious diseases over the centuries have become a major threat to the existence of mankind as they continue to negatively impact society significantly [2]. The pathogenic agents such as bacteria, viruses, fungi, and parasites continue to emerge and are on the upsurge especially in the $21^{\text {st }}$ century despite several attempts to curtail them [3]. Infectious diseases account for the death of about
17 million people annually, with the emergence of at least thirty new diseases. The world is currently battling the pandemic COVID-19 caused by corona virus that has already claimed over 25,000 lives globally within three months (WHO, 2020). These diseases threaten the health of millions of people especially as no cure or vaccine exists. The increasing trend of microbial infections is largely due to the perennial issue of antimicrobial resistance which has been on the ascendency. Key myriad causes of antimicrobial resistance include prolonged chemotherapy and noncompliance to dosage regimen [4].

The growing resistance to antibiotics has led to the increasing trend of pathogens like methicillin resistant Staphylococcus aureus (MRSA), multidrug resistant Mycobacterium tuberculosis (MDR-TB), and multidrug resistant 
Escherichia coli (MDR-Escherichia coli) [5, 6]. Moreover, of most concern in the treatment of nosocomial infections are the ESKAPE pathogens (Enterococcus faecium, Staphylococcus aureus, Klebsiella pneumoniae, Acinetobacter baumannii, Pseudomonas aeruginosa, and Enterobacter species) [7]. Their presence in infections has been a worrying situation in the health sector since most of them are resistant to many antibiotics, and understanding the mechanism of resistance of these strains is useful in the development of novel antimicrobial agents $[8,9]$.

The World Health Organization has made it clear that the trend of increasing infectious diseases would continue due to a number of factors including rural-urban migration, increase in global population, microbial adaptation, and climate change [10]. These would favor the emergence and spread of pathogens, so stakeholders including medicinal chemists are continuously urged to design strategies to discover new chemotherapeutic agents to overcome the antimicrobial resistance menace [11]. Resistant modulatory activity of a compound is the ability of the compound to have controlling influence on the already known standards especially in a positive way. Due to the increasing resistance of microorganisms to antibiotics, agents from natural or synthetic sources seem to modulate the activity of some standard antimicrobial agents such as amoxicillin (a), ciprofloxacin (b), and fluconazole (c) (Figure 1).

Resistance modulatory activities of products (both natural and synthetic) on standard antibiotics have gained scientific interest in recent years. This aims at maximizing antimicrobial potency with major strides in curbing microbial resistance and hence leading to potential drug discovery. An important class of such synthetic agents with promising resistance modulation effect is hydrazones [11]. Hydrazones and their analogues possess the azomethine functionality, an important group of compounds with broad spectrum of biological activities [11, 12]. Hydrazones were chosen due to their wide array of pharmacological activities such as anticonvulsant, anti-inflammatory, antimicrobial, antiprotozoal, and anticancer activities. They play crucial roles not only in biology but also in the fields of photochemistry, analytical chemistry, and inorganic chemistry. Hydrazones are related to ketones and aldehydes by substitution of oxygen with $-\mathrm{NNH}_{2}$ functional moiety $[13,14]$. Due to varying synthetic protocols and detailed structureactivity relationship (SAR) studies, different hydrazone derivatives have been developed and discovered to be pharmacologically active at various targets [15]. Some hydrazone derivatives of isonicotinoyl were found to possess antitubercular activity. Furthermore, benzoic acid hydrazone derivative 4-hydroxybenzoic acid [(5-nitro-2-furyl) methylene]-hydrazide (nifuroxazide) was found to be active against intestinal worms, and derivative 4-fluorobenzoic acid [(5-nitro-2-furyl) methylene]-hydrazide showed antibacterial activity against Staphylococcus aureus ATCC 29213 at $3.13 \mu \mathrm{g} / \mathrm{mL}$ and susceptible Mycobacterium tuberculosis strain H37RV also at $3.13 \mu \mathrm{g} / \mathrm{mL}[16,17]$. Recently synthesized hydrazones including nifuroxazide were found to be active against Mycobacterium tuberculosis strain H37RV at minimum inhibitory concentration range of $0.78-6.25 \mu \mathrm{g} /$ ml. A new agent, 3, 5-dibenzoylvanillin hydrazone, and transition metal complexes were found to exhibit impressive antibacterial activity $[18,19]$.

Hence in this study, six novel phenylhydrazone derivatives have been successfully synthesized by nucleophilic condensation reaction, with their antimicrobial activities and resistance modulation effects investigated.

\section{Materials and Methods}

2.1. Synthesis: General Materials and Methods. A round bottom flask $(100 \mathrm{~mL})$ equipped with a magnetic stirring bar was charged with 2,4-dinitrophenylhydrazine (1 eq.) in methanol $(10 \mathrm{~mL})$ maintained in an ice bath. The resulting suspension was stirred and cooled to $0^{\circ} \mathrm{C}$ before adding concentrated $\mathrm{H}_{2} \mathrm{SO}_{4}(98 \% \mathrm{v} / \mathrm{v}, 2 \mathrm{~mL})$ dropwise which gave a pale yellow solution. After cooling to room temperature, an aldehyde or ketone derivative (1.04 eq.) in methanol (5 mL) was added and the mixture stirred until there was a gradual formation of precipitate which was left for 24 hours. The progress of the chemical reactions was monitored by thin layer chromatography (TLC) intermittently using aluminium plates coated with silica gel $\left(60 \mathrm{GF}_{254}\right)$. The plates were visualized under UV light at $254 \mathrm{~nm}$ and $366 \mathrm{~nm}$, which was followed by spraying with anisaldehyde for spot identity confirmation. The crude product was filtered by suction filtration and recrystallized from hot absolute ethanol (96\% $\mathrm{v} / \mathrm{v})$. The solid product was obtained by suction filtration, dried, and stored at room temperature.

The structures of the synthesized compounds were established with melting point determinations, mass spectroscopy, 1D NMR (proton and carbon-13), and 2D NMR (DEPT-Q) spectroscopy with the support of infrared (IR) and ultraviolet-visible (UV-Vis) spectroscopy techniques [20].

2.1.1. 1-(2,4-Dinitrophenyl)-2-(diphenylmethylene) Hydrazine $\left[\mathrm{C}_{19} \mathrm{H}_{14} \mathrm{~N}_{4} \mathrm{O}_{4}, 1\right]$. 2, 4-Dinitrophenylhydrazine $(0.50 \mathrm{~g}$, $2.74 \mathrm{mmol}, 1$ eq.) in the presence of benzophenone $(0.53 \mathrm{~g}$, 1.04 eq., $2.64 \mathrm{mmol}$ ) yielded the crude product which was purified by recrystallization from hot ethanol to obtain the product [1] $(0.84 \mathrm{~g}, 85 \%)$ as a light orange solid. $R_{f}$ (Pet. ether 70\%: EtOAc 30\%): 0.90. Mpt: $141-143^{\circ} \mathrm{C}$; UV-V is $(\mathrm{MeOH}) \lambda_{\max }: 382 \mathrm{~nm}$. Infrared (neat) $v_{\max } \mathrm{cm}^{-1}: 3382$ $(\mathrm{OH}), 3286(\mathrm{NH}), 1586(\mathrm{C}=\mathrm{CH}), 848,614$ (ArH). 1H NMR $\left(400 \mathrm{MHz}, \mathrm{CDCl}_{3}\right): \delta_{H} 11.24(1 \mathrm{H}, \mathrm{H}-\mathrm{C} 1, s, \mathrm{NH}), 9.09-9.10$ $(1 \mathrm{H}, \mathrm{H}-\mathrm{C} 3, s, \mathrm{ArH}), 8.41\left({ }^{1} \mathrm{H}, \mathrm{H}-\mathrm{C} 5, d, J=2.4, \mathrm{ArH}\right)$, 8.37-8.38 (1H, H-C6, $m, \mathrm{ArH}), 7.66-7.72$ (5H, H-C4', H-C5', H-C6', H-C5', H-C3', m, ArH), 7.35 (3H, H-C6", $\left.\mathrm{H}-\mathrm{C} 5^{\prime \prime}, \mathrm{H}-\mathrm{C} 4^{\prime \prime}, m, \mathrm{ArH}\right), 7.57$ (2H, H-C5', H-C3', $\left.m, \mathrm{ArH}\right)$ ppm. $\left.{ }^{13} \mathrm{C} \mathrm{NMR} \mathrm{(400} \mathrm{MHz;} \mathrm{CDCl}_{3}\right) \delta_{c} 155.7,145.1,136.5$, $131.9,130.5,130.4,130.1,129.9,128.6,128.2,127.9,123.4$, $116.6 \mathrm{ppm}$.

2.1.2. 1-Benzylidene-2-(2,4-dinitrophenyl) Hydrazine $\left[\mathrm{C}_{13} \mathrm{H}_{10} \mathrm{~N}_{4} \mathrm{O}_{4}, 2\right]$. 2, 4-Dinitrophenylhydrazine $(0.90 \mathrm{~g}$, $4.53 \mathrm{mmol}, 1 \mathrm{eq}$.) in the presence of benzaldehyde $(0.50 \mathrm{~g}$, 1.04 eq., $4.71 \mathrm{mmol}$ ) yielded the crude product which was 


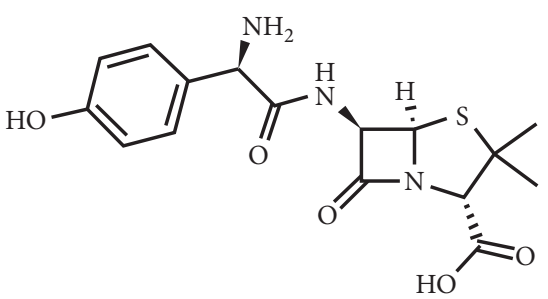

(a)<smiles>O=C(O)c1cn(C2CC2)c2cc(N3CCNCC3)c(F)cc2c1=O</smiles>

(b)

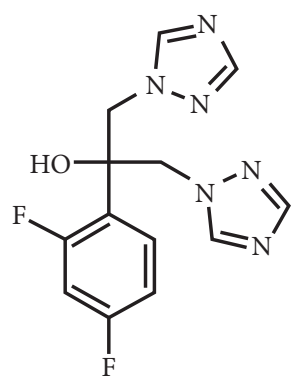

(c)

FIGURE 1: Chemical structures of some standard antibiotics [11]: (a) amoxicillin; (b) ciprofloxacin; (c) fluconazole.

purified by recrystallization from hot ethanol to obtain the product [2] $(1.01 \mathrm{~g}, 78 \%)$ as a yellow solid. $R_{f}$ (Pet. ether 70\%: EtOAc 30\%): 0.83 . Mpt: $178-180^{\circ} \mathrm{C}$; UV-V is $(\mathrm{MeOH})$ $\lambda_{\max }: 224 \mathrm{~nm}$ and $378 \mathrm{~nm}$. Infrared (neat) $v_{\max } \mathrm{cm}^{-1}: 3337$ $(\mathrm{OH}), 3283(\mathrm{NH}), 3100(\mathrm{C}=\mathrm{CH}), 1618,1584(\mathrm{ArC}=\mathrm{C}) .{ }^{1} \mathrm{H}$ NMR $\left(400 \mathrm{MHz}, \mathrm{CDCl}_{3}\right) \delta_{H} 11.24(1 \mathrm{H}, \mathrm{H}-\mathrm{Cl}, s, \mathrm{NH}), 9.09$ $(1 \mathrm{H}, \mathrm{H}-\mathrm{C} 3, s, \mathrm{ArH}), 8.30-8.31\left(1 \mathrm{H}, \mathrm{H}-\mathrm{Cl}^{\prime}, s, \mathrm{~N}=\mathrm{CH}\right), 8.05$ $(1 \mathrm{H}, \mathrm{H}-\mathrm{C} 5, m, \mathrm{ArH}), 8.02(1 \mathrm{H}, \mathrm{H}-\mathrm{C} 6, m, \mathrm{ArH}), 7.41-7.69$ $\left(2 \mathrm{H}, \mathrm{H}-\mathrm{C} 2^{\prime}, \mathrm{H}-\mathrm{C} 6{ }^{\prime}, m, \mathrm{ArH}\right), 7.40\left(1 \mathrm{H}, \mathrm{H}-\mathrm{C} 4^{\prime}, m, \mathrm{ArH}\right), 7.39$ $\left(2 \mathrm{H}, \mathrm{H}-\mathrm{Cl}^{\prime}, \mathrm{H}-\mathrm{C}^{\prime}, m, \mathrm{ArH}\right) .{ }^{13} \mathrm{C}$ NMR $\left(400 \mathrm{MHz}, \mathrm{CDCl}_{3}\right)$ $\delta_{c} 147.9,145.8,144.9,144.7,131.0,130.0,129.0,127.6,123.5$, $116.8 \mathrm{ppm}$.

2.1.3. 3-(2-2-(4-Dinitrophenyl) Hydrazono) Methylphenol $\left[\mathrm{C}_{13} \mathrm{H}_{10} \mathrm{~N}_{4} \mathrm{O}_{5}, 3\right] .2$, 4-Dinitrophenylhydrazine $(0.78 \mathrm{~g}$, $3.93 \mathrm{mmol}, 1$ eq.) in the presence of $m$-hydroxybenzaldehyde $(0.50 \mathrm{~g}, 1.04$ eq., $4.09 \mathrm{mmol})$ yielded the crude product which was purified by recrystallization from hot ethanol to obtain the product $(0.76 \mathrm{~g}, 64 \%)$ as a dark red solid. $R_{f}$ (Pet. Ether 70\%: EtOAc 30\%): 0.74. Mpt: $277-280^{\circ} \mathrm{C}$. UV-Vis $(\mathrm{MeOH})$ $\lambda_{\max }: 392 \mathrm{~nm}$. Infrared (neat) $v_{\max } \mathrm{cm}^{-1}: 3420(\mathrm{OH}), 3257$ $(\mathrm{NH}), 3116(\mathrm{C}=\mathrm{CH}), 1607,1584(\mathrm{ArC}=\mathrm{C}) .{ }^{1} \mathrm{H}$ NMR $\left(400 \mathrm{MHz}, \mathrm{CDCl}_{3}\right) \delta_{H} 11.56(1 \mathrm{H}, \mathrm{H}-\mathrm{Cl}, s, \mathrm{NH}), 10.04(1 \mathrm{H}$, $\left.\mathrm{H}-\mathrm{C} 2^{\prime}, s, \mathrm{ArOH}\right), 8.88(1 \mathrm{H}, \mathrm{H}-\mathrm{C} 3, s, \mathrm{ArH}), 8.86(1 \mathrm{H}, \mathrm{H}-\mathrm{C} 7, s$, $\mathrm{N}=\mathrm{CH}$ ), 8.35-8.37 (1H H-C5, $d, J=8.0, \mathrm{ArH}), 8.08-8.34$ $(1 \mathrm{H}, \mathrm{H}-\mathrm{C} 6), d, J=12.0, \mathrm{ArH}), 8.05\left(1 \mathrm{H}, \mathrm{H}-\mathrm{C}^{\prime}, m, \mathrm{ArH}\right), 7.66$ $\left(1 \mathrm{H}, \mathrm{H}-\mathrm{Cl}^{\prime}, s, \mathrm{ArH}\right), 7.14\left(1 \mathrm{H}, \mathrm{H}-\mathrm{C} 4^{\prime}, m, \mathrm{ArH}\right), 6.87-6.89$ $\left(1 \mathrm{H}\left(\mathrm{H}-\mathrm{C} 3{ }^{\prime}, m, \mathrm{ArH}\right) .{ }^{13} \mathrm{C} \mathrm{NMR}\left(400 \mathrm{MHz}, \mathrm{CDCl}_{3}\right) \delta_{c} 160.5\right.$, $150.5,144.9,137.1,130.2,129.8,129.5,125.2,123.6,117.1$, $116.4 \mathrm{ppm}$.

2.1.4. 4-(2-(2,4-Dinitrophenyl) Hydrazono) Methyl)-2-methoxyphenol $\left[\mathrm{C}_{14} \mathrm{H}_{12} \mathrm{~N}_{4} \mathrm{O}_{6}, 4\right] .2$ 4-Dinitrophenylhydrazine $(0.78 \mathrm{~g}, 3.93 \mathrm{mmol}, 1$ eq. $)$ in the presence of 4-hydroxy-3methoxybenzaldehyde (vanillin) (0.50 g, 1.04 eq., $4.09 \mathrm{mmol}$ ) yielded the crude product which was purified by recrystallization from hot ethanol to obtain the product [4] $(0.91 \mathrm{~g}, 70 \%)$ as a bright red solid. $R_{f}$ (Pet. ether $70 \%$ : EtOAc 30\%): 0.66. Mpt: $270-273^{\circ} \mathrm{C}$. UV-Vis $(\mathrm{MeOH}) \lambda_{\max }: 218 \mathrm{~nm}$ and $394 \mathrm{~nm}$. Infrared (neat) $v_{\max } \mathrm{cm}^{-1}: 3363(\mathrm{OH}), 3274$ $(\mathrm{NH}), 3111(\mathrm{C}=\mathrm{CH}), 1605(\mathrm{ArC}=\mathrm{C}), 699(\mathrm{ArH}) .{ }^{1} \mathrm{H}$ NMR $\left(400 \mathrm{MHz}, \mathrm{CDCl}_{3}\right) \delta_{H} 11.58(1 \mathrm{H}, s, \mathrm{NH}), 10.11\left(1 \mathrm{H}, \mathrm{H}-\mathrm{C}^{\prime}, s\right.$, ArOH), $9.94(1 \mathrm{H}, \mathrm{H}-\mathrm{C} 3, s, \mathrm{ArH}), 8.87(1 \mathrm{H}, \mathrm{H}-\mathrm{C} 5, s, \mathrm{ArH})$, $8.86(1 \mathrm{H}, \mathrm{H}-\mathrm{C} 7, s, \mathrm{~N}=\mathrm{CH}), 8.35(1 \mathrm{H}, \mathrm{H}-\mathrm{C} 6, d, J=4.0, \mathrm{ArH})$, $7.97\left(1 \mathrm{H}, \mathrm{H}-\mathrm{C} 2{ }^{\prime}, d, J=4.0, \mathrm{ArH}\right), 7.66-7.76\left(1 \mathrm{H}, \mathrm{H}-\mathrm{C}^{\prime}{ }^{\prime}, d\right.$, $J=8.0, \mathrm{ArH}), 6.38-6.35\left(1 \mathrm{H}, \mathrm{H}-\mathrm{C}^{\prime}, d, J=12.0, \mathrm{ArH}\right),(3 \mathrm{H}$, $\left.\mathrm{H}-\mathrm{C} 4^{\prime}, \mathrm{Ar}-\mathrm{OCH}_{3}\right) \cdot{ }^{13} \mathrm{C} \mathrm{NMR}\left(400 \mathrm{MHz}, \mathrm{CDCl}_{3}\right) \delta_{c} 150.7$, $150.2,148.6,144.9,137.1,130.2,125.6,123.6,123.1,117.2$, $116.1,110.3,56.2 \mathrm{ppm}$.

2.1.5. (Z)-2-(2, 4-Dinitrophenyl) Hydrazono) Methyl Phenol $\left[\mathrm{C}_{13} \mathrm{H}_{10} \mathrm{~N}_{4} \mathrm{O}_{5}, 5\right] .2$, 4-Dinitrophenylhydrazine $(0.78 \mathrm{~g}$, $3.93 \mathrm{mmol}, 1 \mathrm{eq}$.) in the presence of salicylaldehyde $(0.50 \mathrm{~g}$, $4.09 \mathrm{mmol}, 1.04$ eq.) yielded the crude product which was purified by recrystallization from hot ethanol to obtain the product [5] (1.09 g, 92\%) as a bright orange solid. $R_{f}$ (Pet. ether 70\%: EtOAc 30\%): 0.84. Mpt: $176-180^{\circ} \mathrm{C}$; UV-Vis $(\mathrm{MeOH}) \lambda_{\max }: 386 \mathrm{~nm}$. Infrared (neat) $v_{\max }\left(\mathrm{cm}^{-1}\right): 3334$ $(\mathrm{OH}), 3267(\mathrm{NH}), 3059(\mathrm{C}=\mathrm{CH}), 1583(\mathrm{ArC}=\mathrm{C}), 759$ $(\mathrm{ArH}){ }^{1} \mathrm{H}$ NMR $\left(400 \mathrm{MHz}, \mathrm{CDCl}_{3}\right) \delta_{H} 11.25\left(1 \mathrm{H}, \mathrm{H}-\mathrm{C} 3^{\prime}, s\right.$, ArOH), $9.98(1 \mathrm{H}(\mathrm{C} 1), s, \mathrm{NH}), 9.11(1 \mathrm{H} \mathrm{H}-\mathrm{C} 3, s, \mathrm{ArH})$, 8.34-8.36 $\left(1 \mathrm{H}, \mathrm{H}-\mathrm{Cl}^{\prime}, s, \mathrm{~N}=\mathrm{CH}\right), 8.33(1 \mathrm{H}, \mathrm{H}-\mathrm{C} 5, d, J=4.0$, $\mathrm{ArH}), 7.61-7.58(1 \mathrm{H}, \mathrm{H}-\mathrm{C} 6, d, J=4.0, \mathrm{ArH}), 7.31\left(1 \mathrm{H}, \mathrm{H}-\mathrm{C}^{\prime}\right.$, $m, \mathrm{ArH}), 7.25\left(1 \mathrm{H}, \mathrm{H}-\mathrm{C} 4^{\prime}, m, \mathrm{ArH}\right), 7.24(1 \mathrm{H}, \mathrm{H}-\mathrm{C} 7, m$, ArH $), 6.95\left(1 \mathrm{H}, \mathrm{H}-\mathrm{C5}^{\prime}, m, \mathrm{ArH}\right) \mathrm{ppm} .{ }^{13} \mathrm{C}$ NMR $(400 \mathrm{MHz}$, $\left.\mathrm{CDCl}_{3}\right) \delta_{c} 157.9,151.3,132.9,131.4,130.6,123.7,120.3$, $117.2,116.9,115.3 \mathrm{ppm}$. HRMS (ESI): $m / z$ calculated for [M$\mathrm{H}]^{+} \mathrm{C}_{13} \mathrm{H}_{10} \mathrm{~N}_{4} \mathrm{O}_{5}: 302.2400$, found: 301.0000 .

2.1.6. 4-(2-(2, 4-Dinitrophenylhydrazono) Methyl) Benzene1, 3-diol $\left[\mathrm{C}_{13} \mathrm{H}_{10} \mathrm{~N}_{4} \mathrm{O}_{6}, 6\right]$. 2, 4-Dinitrophenylhydrazine $(0.69 \mathrm{~g}, 3.48 \mathrm{mmol}, 1$ eq. $)$ in the presence of 2, 4-dihydroxy benzaldehyde $(0.50 \mathrm{~g}, 1.04$ eq., $3.62 \mathrm{mmol})$ yielded the crude product which was purified by recrystallization from hot ethanol to obtain the product [6] $(0.66 \mathrm{~g}, 2.07 \mathrm{mmol}, 60 \%)$ as a dark red solid. $R_{f}$ (Pet. ether 70\%: EtOAc 30\%): 0.51 . Mpt: 270-274 ${ }^{\circ} \mathrm{C}$; UV-Vis $(\mathrm{MeOH}) \lambda_{\text {max }}: 403 \mathrm{~nm}$. Infrared (neat) $v_{\max }\left(\mathrm{cm}^{-1}\right): 3364(\mathrm{OH}), 3094(\mathrm{C}=\mathrm{CH}), 1612,1584$ $(\mathrm{ArC}=\mathrm{C}) 592(\mathrm{ArH}) .{ }^{1} \mathrm{H}$ NMR $\left(400 \mathrm{MHz}, \mathrm{DMSO}^{-} \mathrm{d}_{6}\right) 11.58$ $\left(1 \mathrm{H}, \mathrm{H}-\mathrm{C} 3^{\prime}, s, \mathrm{ArOH}\right), 10.11(1 \mathrm{H}, \mathrm{H}-\mathrm{Cl}, s, \mathrm{NH}), 9.94(1 \mathrm{H}$, $\left.\mathrm{H}-\mathrm{C}^{\prime}, s, \mathrm{ArOH}\right), 8.87(1 \mathrm{H}, \mathrm{H}-\mathrm{C} 3, s, \mathrm{ArH}), 8.86(1 \mathrm{H}, s$, $\mathrm{N}=\mathrm{CH}), 8.33\left(1 \mathrm{H}, \mathrm{H}-\mathrm{C}^{\prime}, s, \mathrm{ArH}\right), 8.36(1 \mathrm{H}, \mathrm{H}-\mathrm{C} 5, d$, $J=12.0, \mathrm{ArH}), 7.95-7.97(1 \mathrm{H}, \mathrm{H}-\mathrm{C} 6, d, J=8.0, \mathrm{ArH}), 7.54$ (1H, H-C7, $m, \mathrm{ArH}), 6.38\left(1 \mathrm{H}, \mathrm{H}-\mathrm{C}^{\prime}, d, J=8.0, \mathrm{ArH}\right) \mathrm{ppm}$. ${ }^{13} \mathrm{C}$ NMR $\left(400 \mathrm{MHz}, \mathrm{DMSO}-\mathrm{d}_{6}\right) \delta_{c} 161.8,159.1,148.2,144.6$, $136.7,130.1,129.3,128.8,123.6,116.9,112.0,108.7$, $102.1 \mathrm{ppm}$. 


\subsection{Antimicrobial Evaluation of the Compounds}

2.2.1. Source of Test Organisms. Pure cultures of Staphylococcus aureus (SA) (ATCC 25923), Escherichia coli (EC) (ATCC 25922), and Pseudomonas aeruginosa (PA) (ATCC 27853) were obtained from the Microbiology Division of the Department of Pharmaceutics, Faculty of Pharmacy and Pharmaceutical Sciences, Kwame Nkrumah University of Science and Technology (KNUST), Kumasi. However, Klebsiella pneumoniae (KP), Candida albicans (CA), and Streptococcus pneumoniae (SP) were clinical strains obtained from the Komfo Anokye Teaching Hospital, Kumasi, and cultured in the Department of Pharmaceutics, KNUST.

\subsubsection{Determination of Minimum Inhibitory Concentration} (MIC). The microbroth dilution method was employed for determining the minimum inhibitory concentrations (MICs) of the hydrazone derivatives and the reference drugs ciprofloxacin and fluconazole. 96-well microtiter plates were filled with $125 \mu \mathrm{L}$ of double strength nutrient broth, and different concentrations of the hydrazone derivatives added. The reference drugs in the range $12.5 \mu \mathrm{L} / \mathrm{mL}$ to $40 \mu \mathrm{L} / \mathrm{mL}$ were similarly treated. An aliquot of $1 \times 10^{5} \mathrm{cfu} / \mathrm{mL}$ of test organisms was added to each well. The control plate was filled with nutrient broth and test organisms only. The test and control plates were incubated at $37^{\circ} \mathrm{C}$ (24 hours for bacteria and 48 hours for fungus), after which $20 \mu \mathrm{L}$ of $1.25 \mathrm{mg} / \mathrm{ml}$ of 3-(4,5-dimethylthiazol-2-yl)-2, 5-diphenyltetrazolium bromide (MTT) was introduced into each well. Observations were made after 20 minutes for a purple coloration, which indicates growth. The minimum concentrations of the hydrazone derivatives and reference drugs that did not show color change in the wells were deemed to be the MIC values $[21,22]$. The determinations were carried out in replicates.

2.2.3. Resistant Modulation Studies. For the modulation studies, the 96 -well plates were filled with $125 \mu \mathrm{L}$ of double strength nutrient broth, and the same volume of $40 \mu \mathrm{L}$ phenylhydrazones was added. Different concentrations in the ranges $50 \mu \mathrm{L} / \mathrm{ml}$ to $7.812 \mu \mathrm{L} / \mathrm{ml}$ and $15.625 \mu \mathrm{L} / \mathrm{ml}$ to $7.812 \mu \mathrm{L} / \mathrm{ml}$ of ciprofloxacin and fluconazole were, respectively, added. $25 \mu \mathrm{L}$ containing $1 \times 10^{5} \mathrm{cfu}$ of test organisms was added to each well, and the plates were incubated at $37^{\circ} \mathrm{C}$ (for 24 and 48 hours for bacteria and fungus, respectively), after which $20 \mu \mathrm{L}$ of MTT was added to each well. The appearance of a change in color from cloudy wells to purple was recorded and compared with MICs of the reference drugs only $[22,23]$. The determinations were carried out in replicates.

\section{Results and Discussion}

3.1. Structural Analysis of the Phenylhydrazones. The synthetic route employed for the synthesis of the compounds was followed by the standard condensation reaction between aldehydes or ketones and hydrazines, taking into consideration the commercial availability of the building blocks
(Scheme 1). A retrosynthetic disconnection approach allowed us to identify various aldehydes and a ketone as key intermediates for the synthesis of the desired compounds. The process involves a rate-determining aromatic nucleophilic attack of 2,4-dinitrophenylhydrazine on the carbonyl in an acidified solution. This was followed by dehydration of the reactive intermediate to give the final product 2,4 dinitrophenylhydrazone derivative.

The data for the synthetic procedures are included in the experimental section and interpreted according to the sequence: melting point range (Mpt.) in degree Celsius $\left({ }^{\circ} \mathrm{C}\right)$, wavelength of maximum absorption $\left(\lambda_{\max }\right)$ from the ultraviolet-visible spectrum, infrared spectrum, ${ }^{1} \mathrm{H}$ NMR [chemical shift, integral, multiplicity, coupling constant, and interpretation], ${ }^{13} \mathrm{C} \mathrm{NMR}$, and HRMS as a confirmatory tool for SA5 (compound 5) (one of the most active compounds).

3.1.1. UV-Vis Spectroscopy. The spectra for all the six compounds [refer to high resolution electrospray ionization mass spectrum (HRESIMS)] were determined in both the ultraviolet and visible wavelengths $(200-800 \mathrm{~nm})[23,24]$ as a confirmatory tool for BP1 in the supplementary information using methanol as the blank. The absorption bands at $203 \mathrm{~nm}$ and $403 \mathrm{~nm}$, which were obtained in the electronic spectra of the synthesized phenylhydrazones, can be credited to $\left(\pi-\pi^{*}\right)$ transitions, which are contributed by the various substituent auxochromes on the phenylhydrazones. Phenylhydrazones are known to be absorbed at various wavelengths within the UV-visible range $[25,26]$.

For instance, compound BP1, when dissolved in methanol and scanned within the UV-visible region, showed absorption at $203 \mathrm{~nm}, 314 \mathrm{~nm}$, and $382 \mathrm{~nm}$ which could be attributed to extensive conjugation in the phenylhydrazones after the coupling of benzophenone and 2,4-dinitrophenylhydrazine. However, compound BP1 showed maximum absorption at $382 \mathrm{~nm}$, and this could be attributed to an increase in conjugation. Also, compounds BA2, MHB3, VL4, SA5, and DHB6 showed maximum absorption at $378 \mathrm{~nm}, 392 \mathrm{~nm}, 394 \mathrm{~nm}, 386 \mathrm{~nm}$, and $403 \mathrm{~nm}$, respectively, as observed in the supporting information.

The extensive conjugation can be attributed to the presence of chromophores in the phenylhydrazones which include BP1 (two aromatic ring chromophores), MHB3 (meta hydroxy auxochrome), VL4 (a hydroxy and methoxy auxochrome), SA5 (ortho hydroxy auxochrome), and DHB6 (two hydroxy auxochromes). This suggests that the hydrazones with auxochromes and extra chromophore had extended conjugation leading to a shift in $\lambda_{\max }$ to the right (bathochromic shift).

3.1.2. Infrared Spectroscopy. The infrared spectrum gives an idea of the functional groups in a compound. From the infrared spectrum of compound 5 as a sample, the presence of broad band stretching from around $3300 \mathrm{~cm}^{-1}$ and sloping into the aliphatic $\mathrm{CH}$ region of around $3000 \mathrm{~cm}^{-1}$ indicates the presence of a hydroxy functional group, in this case that of a phenol as observed in the supporting information. 


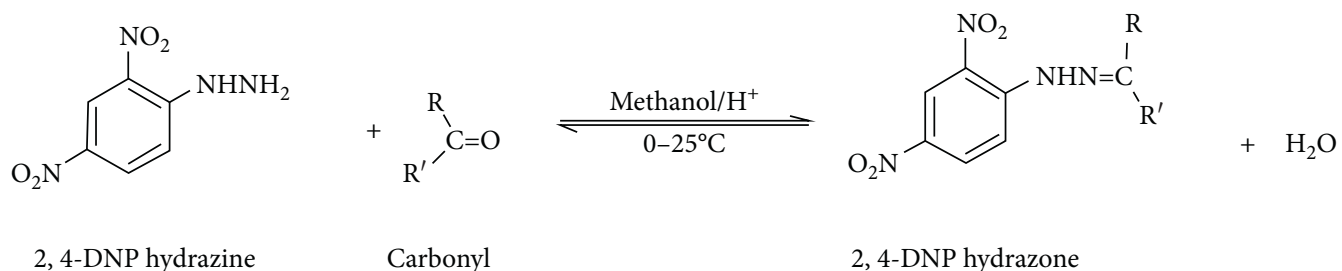

$\begin{array}{ccc}\text { Compound } & \mathrm{R} & \mathrm{R}^{\prime} \\ 1 & -\mathrm{C}_{6} \mathrm{H}_{5} & -\mathrm{C}_{6} \mathrm{H}_{5} \\ 2 & -\mathrm{H} & -\mathrm{C}_{6} \mathrm{H}_{5} \\ 3 & -\mathrm{H} & \mathrm{C}_{6} \mathrm{H}_{5}(m-\mathrm{OH}) \\ 4 & -\mathrm{H} & \mathrm{C}_{6} \mathrm{H}_{5} \mathrm{OH}\left(m-\mathrm{OCH}_{3}\right) \\ 5 & -\mathrm{H} & \mathrm{C}_{6} \mathrm{H}_{5}(o-\mathrm{OH}) \\ 6 & -\mathrm{H} & \mathrm{C}_{6} \mathrm{H}_{5} \mathrm{OH}(m-\mathrm{OH})\end{array}$

SCHEME 1: Synthetic procedures and reagents for compounds 1-6. Reagents and conditions: methanol/concentrated $\mathrm{H}_{2} \mathrm{SO}_{4}(98 \% \mathrm{v} / \mathrm{v}, 2 \mathrm{~mL})$, $0-25^{\circ} \mathrm{C}, 24 \mathrm{~h}$.

It was also observed from the IR spectrum (supplementary information) that compounds like MHB3, VL4, SA5, and DHB6 showed sharp strong peak of their $\mathrm{C}=\mathrm{C}$ stretching band in the region of $1138-1620 \mathrm{~cm}^{-1}$ compared to BP1 and BA2 which do not have the hydroxy function as shown in Table 1 . The presence of the $\mathrm{C}=\mathrm{N}$, which is formed from the condensation reaction between the hydrazine and the carbonyls, was overlapped by aromatic $\mathrm{sp}^{2}$ hybridized carbons $(\mathrm{C}=\mathrm{C})$ in the benzene which vibrate at $1138-1640 \mathrm{~cm}^{-1}$ depending on the substituent attachments. Since $\mathrm{C}=\mathrm{N}$ vibrational frequencies fall within $1580-1600 \mathrm{~cm}^{-1}$, their bands cannot be clearly distinguished in the presence of their aromatic $\mathrm{C}=\mathrm{C}$ counterparts as shown in the experimental data.

3.1.3. Nuclear Magnetic Resonance (NMR) Spectroscopy. NMR determinations were performed for all the six synthesized phenylhydrazones using a one-dimensional (1D) NMR technique $\left({ }^{1} \mathrm{H}\right.$ and $\left.{ }^{13} \mathrm{C}\right)$ and two-dimensional NMR technique, distortionless enhancement by polarization transfer for quaternary carbons (DEPT-Q). These data are assigned to each compound in the experimental section. The structures were confirmed with ${ }^{1} \mathrm{H}$ NMR, ${ }^{13} \mathrm{C} \mathrm{NMR}$, and DEPT-Q spectral data as shown in the supplementary information for compounds BP1, BA2, MHB3, VL4, SA5, and DHB6, respectively. Considering DHB6 (compound 6), [4(2-(2, 4-dinitrophenylhydrazono) methyl) benzene-1, 3diol] (Figure 2, Table 1), and from the proton NMR (supplementary information), a chemical shift showing resonance far downfield signified the presence of the hydroxy proton with a singlet signal. It resonated further downfield than the secondary amine proton because of the increased deshielding effect of the electronegative oxygen [27]. This chemical shift was slightly higher than that of the hydroxyl group ( $\delta 9.94 \mathrm{ppm})$ because the former is closer to the chemical environment of the electronegative nitrogen atom in the imine bond. Hence, the first hydroxy singlet signal at $\delta$ $11.54 \mathrm{ppm}$ was followed by a singlet signal secondary amino proton at $\delta 10.11$ due to electronegativity of the nitrogen group before the other hydroxy signal. The aromatic proton sandwiched between two electronegative nitro groups was the next signal resonating downfield at $\delta 8.86 \mathrm{ppm}$. This was followed by the proton close to the tertiary amino group. The tertiary amino group attached to the imine proton caused deshielding and downfield resonating of imine protons at $\delta$ $8.86 \mathrm{ppm}$ with a singlet signal. The lone proton closest to the nitro group at the para position was the next signal with a doublet peak at $\delta 7.95-7.97 \mathrm{ppm}$. The other lone proton closest to the less electronegative secondary amino group also gave a doublet signal at $\delta 7.64-7.66 \mathrm{ppm}$. The two other lone protons (one in between the diol and the other ortho to the imine bond) gave a multiplet signal at $\delta 7.52-7.54 \mathrm{ppm}$, while the proton closest to the para hydroxy group and two carbon bonds away from the imine group gave a doublet signal at $\delta 6.38 \mathrm{ppm}$.

DEPT-Q is used for the differentiation of the primary, secondary, tertiary, and quaternary carbons. In DEPT-Q, the methyl $\left(\mathrm{CH}_{3}\right)$ and methine $(\mathrm{CH})$ signals appear up in the positive phase, while methylene $\left(\mathrm{CH}_{2}\right)$ and quaternary signals appear down in the negative phase. The DEPT-Q spectrum of DHB6 (supplementary information) reveals the presence of upward carbon signals representing only six methine carbons in this case occurring at $\delta 161.8,159.1$, 148.2 , 136.7, 130.1, and 112.0 confirming the aromatic methine carbons and seven quaternary carbons occurring at $\delta 148.2,130.1,129.2,123.6,116.9,108.7$, and 102.9. The 
TABLE 1: Chemical structures and physical data of the synthesized phenylhydrazones.

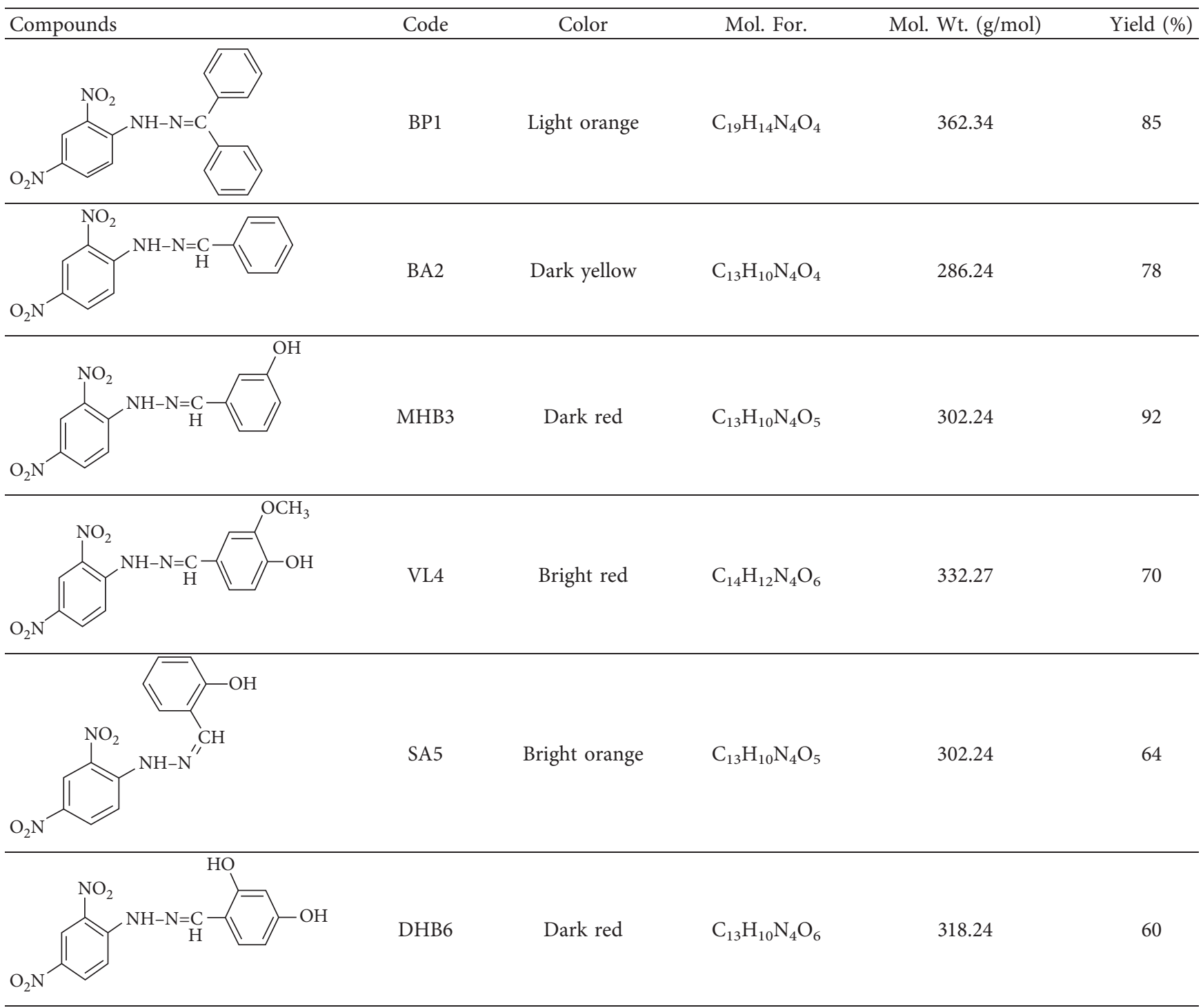<smiles>O=[N+]([O-])c1ccc(N/N=C/c2ccc(O)cc2[N+](=O)[O-])c(O)c1</smiles>

Figure 2: Chemical structure of DBH6 (compound 6) [4-(2-(2, 4dinitrophenylhydrazono) methyl) benzene-1, 3-diol].

DEPT-Q for the other compounds can be found in the supplementary information.

3.1.4. Mass Spectroscopy. Mass spectroscopy is used for the determination of accurate molecular weights and fragmentation of compounds using ionization techniques [28]. Compound SA5 phenylhydrazone was one of the most active compounds after antimicrobial evaluation. From the electrospray ionization (ESI) mass spectrum, the molecular ion peak in negative mode was $301.0000\left(\mathrm{M}-\mathrm{H}^{+}\right)$which is the actual mass having a tolerance range of $0.24(0.41 \%)$ from the theoretical mass of 302.2400. This confirmed the molecular weight of compound SA5.

The mass spectroscopy was used to confirm the molecular weight of one of the most active compounds and hence was not applied to the others.

\section{Antimicrobial Evaluation}

4.1. Minimum Inhibitory Concentrations (MICs). Minimum inhibitory concentration (MIC) is the least concentration of an antimicrobial agent that would inhibit the visible growth of the pathogen after $24 \mathrm{~h}$ (bacteria) and $48 \mathrm{~h}$ (fungi) incubation [28]. The MICs of the phenylhydrazones and two standard antibiotics (ciprofloxacin and fluconazole) were evaluated with the microbroth dilution test against a panel of six pathogenic microorganisms: Gram-negatives $[P$. aeruginosa (ATCC 27853), E. coli (ATCC 25922), K. pneumoniae (clinical)], Gram-positives 
TABLE 2: Antimicrobial activity of the compounds against the panel of organisms.

\begin{tabular}{|c|c|c|c|c|c|c|c|c|}
\hline \multirow{2}{*}{ Test organisms } & \multicolumn{8}{|c|}{ Minimum inhibitory concentrations $(\mu \mathrm{M})$ of the phenylhydrazones } \\
\hline & BP1 & BA2 & MHB3 & VL4 & SA5 & DHB6 & $\mathrm{CPR}$ & FLZ \\
\hline Staphylococcus aureus (+) & $>552$ & 699 & $>662$ & 602 & 662 & $>628$ & 4.72 & $\mathrm{Nd}$ \\
\hline Streptococcus pneumoniae $(+)$ & 552 & 699 & $>662$ & 300.96 & 165 & 314 & 2.36 & $\mathrm{Nd}$ \\
\hline Escherichia coli $(-)$ & $>552$ & 699 & $>662$ & 602 & 662 & 628 & 4.72 & $\mathrm{Nd}$ \\
\hline Pseudomonas aeruginosa (-) & $>552$ & $>699$ & $>662$ & 602 & 662 & 628 & 2.36 & $\mathrm{Nd}$ \\
\hline Klebsiella pneumoniae $(-)$ & 138 & 699 & $>662$ & 602 & 331 & 314 & 2.36 & $\mathrm{Nd}$ \\
\hline Candida albicans & 552 & 699 & $>562$ & 602 & 662 & 314 & $\mathrm{Nd}$ & 327 \\
\hline
\end{tabular}

BP1 [benzophenone derivative], BA2 [benzaldehyde derivative], MHB3 [m-hydroxy benzaldehyde], VL4 [vanillin derivative], SA5 [salicylaldehyde derivative], DHB6 [2, 4-dihydroxybenzaldehyde derivative]; standard antibiotics: CPR [ciprofloxacin] and FLZ [fluconazole]. Nd [not determined]. All tests were carried out in triplicate $(n=3)$.

TABLE 3: Resistant modulatory activity of the compounds against the panel of organisms.

\begin{tabular}{lcccccrrr}
\hline \multirow{2}{*}{ Test organisms } & \multicolumn{4}{c}{ Minimum inhibitory concentrations $(\mu \mathrm{M})$ of the phenylhydrazones } \\
& BP1 & BA2 & MHB3 & VL4 & SA5 & DHB6 & CPR & FLZ \\
\hline Staphylococcus aureus $(+)$ & $>138$ & 87.3 & 165 & $>150$ & $>165$ & $>157$ & 4.72 \\
Streptococcus pneumoniae (+) & 1.078 & 1.36 & 1.29 & 1.176 & 1.29 & 1.23 & 2.36 \\
Escherichia coli (-) & $>138$ & $>175$ & $>165$ & $>150$ & $>165$ & $>157$ & 4.72 & - \\
Pseudomonas aeruginosa (-) & $>17.2$ & 87.3 & 82.7 & 75.2 & 2.58 & 39.3 & 2.36 & - \\
Klebsiella pneumoniae (-) & 1.078 & 5.46 & 1.29 & 1.176 & 1.29 & 1.23 & 2.36 \\
Candida albicans & 2.156 & 273 & 5.109 & 1.176 & 1.29 & 1.23 & - \\
\hline
\end{tabular}

[S. aureus (ATCC 25923), S. pneumoniae (clinical strain)], and $C$. albicans (fungus, clinical strain).

All the compounds showed weak antimicrobial activity against test organisms at test concentrations as observed in Table 2. BP1 showed the highest antimicrobial activity among the six compounds against the selected test organisms. BA2, however, had the least antimicrobial activity with MIC of $699 \mu \mathrm{M}$ against the entire test organisms. MHB3 had MIC of $562 \mu \mathrm{M}$ against $C$. albicans and $662 \mu \mathrm{M}$ and above against the rest of the test organisms. VL4 recorded an MIC of $602 \mu \mathrm{M}$ against all test organisms except $S$. pneumoniae $(\mathrm{MIC}=300 \mu \mathrm{M})$. The MICs of SA5 against $S$. pneumoniae and K. pneumoniae were $165 \mu \mathrm{M}$ and $331 \mu \mathrm{M}$, respectively, while for $S$. aureus, E. coli, P. aeruginosa, and C. albicans it had a higher MIC of $662 \mu \mathrm{M}$. DHB6 showed activity against S. pneumoniae, K. pneumoniae, and C. albicans with MIC of $314 \mu \mathrm{M}$, while for $S$. aureus, E. coli, and P. aeruginosa it had MIC of $628 \mu \mathrm{M}$ and above. The reference antibacterial drug used was ciprofloxacin, and the MICs recorded were $2.36 \mu \mathrm{M}$ against P.aeruginosa, S. pneumoniae, and K. pneumoniae, while $4.72 \mu \mathrm{M}$ was recorded against $S$. aureus and $E$. coli. The reference antifungal drug used was fluconazole, and the MIC obtained was $327 \mu \mathrm{M}$ against $C$. albicans. The MIC of the phenylhydrazones against the two Gram-negative organisms ranged from $552 \mu \mathrm{M}$ to $699 \mu \mathrm{M}$, while the standard ciprofloxacin was at 4.72 and $2.36 \mu \mathrm{M}$, respectively (Table 2 ).

4.2. Resistant Modulation Activity. The tendency of the phenylhydrazones at sub-MICs to improve the activities of some commercial antibiotics against known resistant strains was investigated through the resistant modulation test. From Tables 2 and 3, BP1 (compound 1) with sub-MIC of $50 \mu \mathrm{M}$ against S. pneumoniae lowered the MIC of ciprofloxacin from 2.36 to $1.078 \mu \mathrm{M}$ representing $54.32 \%$ reduction in the MIC of the ciprofloxacin. BP1 also improved the performance of the ciprofloxacin at sub-MIC of $50 \mu \mathrm{M}$ against $K$. pneumoniae from $2.36 \mu \mathrm{M}$ to $1.078 \mu \mathrm{M}$ representing $54.32 \%$ reduction in the MIC of the antibiotics. Again, BP1 modulated the activity of fluconazole against $C$. albicans from 327 to $2.156 \mu \mathrm{M}$ representing $99.34 \%$ reduction in the MIC of the fluconazole. Similarly, BA2 improved the activity of ciprofloxacin against $S$. pneumoniae and reduced the MIC of ciprofloxacin from 2.36 to $1.36 \mu \mathrm{M}$ showing $42.37 \%$ reduction. In addition, BA 2 also modulated the activity of fluconazole at sub-MIC of $50 \mu \mathrm{M}$ against $C$. albicans and caused a reduction in its MIC from 327 to $1.23 \mu \mathrm{M}$ which is indicative of $99.6 \%$ reduction in the MIC.

MHB3 modulated the activity of the ciprofloxacin against S. pneumoniae and Klebsiella pneumoniae causing a reduction in the MIC of antibiotics from 2.36 to $1.29 \mu \mathrm{M}$. This decrease in the MIC indicated a reduction of $45.33 \%$. MHB3 also showed the modulation of the activity of fluconazole at subMIC of $50 \mu \mathrm{M}$ against Candida albicans and lowered the MIC to 5.109 from $327 \mu \mathrm{M}$ indicating a maximum reduction of 98.43\%. VL4 enhanced the performance of ciprofloxacin at sub-MIC of $50 \mu \mathrm{M}$ against $S$. pneumoniae and K. pneumoniae. The MIC of the antibiotic decreased from 2.36 to $1.176 \mu \mathrm{M}$. in both instances. This decrease in MIC depicted $50.17 \%$ reduction. VL4 again modulated the performance of fluconazole at sub-MIC of $50 \mu \mathrm{M}$ against C. albicans and lowered the MIC to $1.176 \mu \mathrm{M}$ from $327 \mu \mathrm{M}$, which showed a maximum reduction of $99.64 \%$.

In addition, compound 5 (SA5) modulated the activity of the ciprofloxacin at sub-MIC of $50 \mu \mathrm{M}$ against $S$. pneumoniae and K. pneumoniae. The MIC was lowered from 2.36 to 
$1.29 \mu \mathrm{M}$ in both cases resulting in $45.34 \%$ reduction. SA5 again modulated the performance of fluconazole at subMIC of $50 \mu \mathrm{M}$ against C. albicans and suppressed its MIC from 327 to $1.29 \mu \mathrm{M}$, indicating a good reduction of $99.61 \%$. DHB6 (compound 6) also modulated the activity of ciprofloxacin at sub-MIC of $50 \mu \mathrm{M}$ against $S$. pneumoniae and K. pneumoniae and lowered its MIC from 2.36 to $1.23 \mu \mathrm{M}$ in both instances representing $47.88 \%$ reduction in the MIC. DHB6 also modulated the activity of fluconazole at sub-MIC of $50 \mu \mathrm{M}$ against C. albicans and lowered its MIC from $327 \mu \mathrm{M}$ to $1.23 \mu \mathrm{M}$ representing $99.62 \%$ reduction in MIC. SA5 and BP1 were better than the other four phenylhydrazones in resistance modulatory activity together with ciprofloxacin which had MIC of $2.58 \mu \mathrm{M}$ against P.aeruginosa, followed by BP1 $(17.2 \mu \mathrm{M})$. Hence, the presence of an ortho hydroxy group in SA5 and aromatic ketone group might be essential for resistant modulatory activity in combination with ciprofloxacin against Gram-negative P.aeruginosa and E. coli. Furthermore, the presence of meta hydroxy group (MHB3), a hydroxy and methoxy (VL4), and absence of a substituent on the benzaldehyde portion of BA2 also improved activity and could be considered for future drug development. K. pneumoniae, the other Gram-negative counterpart which causes serious infections, was more susceptible to the phenylhydrazones at 138 to $699 \mu \mathrm{M}$. By the combination of subinhibitory concentrations of the phenylhydrazones with ciprofloxacin, the resistance barrier of $K$. pneumoniae was reduced allowing for a far lower MIC of 1.078 from $5.46 \mu \mathrm{M}$, a trend that is more impressive than that of $P$. aeruginosa and E.coli.

The phenylhydrazones had similar activity against the Gram-positive organisms ranging from 87.3 to $699 \mu \mathrm{M}$ which is also evident of the resistant properties of Staphylococcus aureus and Streptococcus pneumoniae.

\section{Conclusion}

A library of six novel phenylhydrazones was successfully synthesized and characterized: 1-(2, 4-dinitrophenyl)-2(diphenylmethylene) hydrazine [BP1], 1-benzylidene-2-(2, 4-dinitrophenyl) hydrazine [BA2], 3-(2-2-(4-dinitrophenyl) hydrazono) methylphenol, 4-(2-(2, 4-dinitrophenyl) hydrazono) methyl)-2-methoxyphenol [VL4], (Z)-2-(2, 4dinitrophenyl) hydrazono) methylphenol [SA5], and 4-(2(2, 4-dinitrophenylhydrazono) methyl) benzene-1, 3-diol.

As part of future drug design and optimization, the phenylhydrazones can be considered as structural backbones due to their synthetic feasibility and good yield. The compounds exhibited weak antimicrobial property but demonstrated strong resistant modulating action when combined with the standard drugs. The activities of the standards improved significantly with a good reduction in the MIC values.

\section{Abbreviations}

MRSA: Methicillin resistant Staphylococcus aureus

ATCC: American type culture collection
NTCC: National collection of type cultures

MTT: $\quad$ (4, 5-Dimethylthiazol-2-yl)-2, 5-

diphenyltetrazolium bromide

MIC: $\quad$ Minimum inhibitory concentration

TLC: Thin layer chromatography

Cfu: $\quad$ Colony forming units

Eq.: $\quad$ Equivalent

DEPT-Q: Distortionless enhancement of polarization transfer for quaternary carbons

HRSMS: High resolution mass spectrum.

\section{Data Availability}

Data of the research is available in the archives of the Department of Pharmaceutical Chemistry, Faculty of Pharmacy, Kwame Nkrumah University of Science and Technology.

\section{Conflicts of Interest}

The authors declare no conflicts of interest regarding the publication of this paper.

\section{Authors' Contributions}

A.A., A.B., I.A., Y.D.B., C.D.K.A., and B.K.H. conceived the research work and prepared the manuscript. C.D. K.A., A.B., and A.A. designed and carried out the synthesis of the compounds. C.D.K.A., A.A., and I.A. developed the conceptual framework and prepared the manuscript. C.D.K.A. and B.K.H. interpreted the spectral results and carried out the structure elucidation. Y.D.B. and A.A. carried out the in vitro antimicrobial assay and provided its experimental data and interpretation of the results.

\section{Acknowledgments}

The authors are very grateful to all the staff and technicians of the Department of Pharmaceutical Chemistry, Faculty of Pharmacy, KNUST, Kumasi, Ghana, for their support. The authors greatly acknowledge Mr. Francis Amankwah of the Department of Pharmaceutics (Microbiology Section), KNUST, for the technical support.

\section{Supplementary Materials}

The supplementary file contains all the spectra. (Supplementary Materials)

\section{References}

[1] F. Fenollar and O. Mediannikov, "Emerging infectious diseases in Africa in the $21^{\text {st }}$ century," New Microbes and New Infections, vol. 26, pp. S10-S18, 2018.

[2] E. B. A. Adusei, R. K. Adosraku, J. Oppong-Kyekyeku, C. D. K. Amengor, and Y. Jibira, "Resistance modulation action, time-kill kinetics assay, and inhibition of biofilm formation effects of plumbagin from Plumbago zeylanica Linn," Journal of Tropical Medicine, vol. 2019, Article ID 1250645, 8 pages, 2019. 
[3] A. R. Omran, "The epidemiologic transition: a theory of the epidemiology of population change," Milbank Quarterly, vol. 83, no. 4, pp. 731-757, 2005.

[4] F. Prestinaci, P. Pezzotti, and A. Pantosti, "Resistance: a global multifaceted phenomenon," Pathogens and Global Health, vol. 109, no. 7, pp. 309-318, 2015.

[5] J. Davies and D. Davies, "Origins and evolution of antibiotic resistance," Microbiology and Molecular Biology Reviews, vol. 74, no. 3, pp. 417-433, 2010.

[6] R. H. Dahal and D. K. Chaudhary, "Microbial infections and antimicrobial resistance in Nepal: current trends and recommendations," The Open Microbiology Journal, vol. 12, no. 1, pp. 230-242, 2018.

[7] S. Santajit and N. Indrawattana, "Mechanisms of antimicrobial resistance in ESKAPE pathogens," BioMed Research International, vol. 2016, Article ID 2475067, 8 pages, 2016.

[8] S. Haque, D. A. Nawrot, S. Alakurtti, L. Ghemtio, and J. Ylikauhaluoma, "Screening and characterisation of antimicrobial properties of semisynthetic betulin derivatives," PLoS One, vol. 9, no. 7, 2014.

[9] J. Hyde, C. Gorham, D. E. Brackney, and B. Steven, "Antibiotic resistant bacteria and commensal fungi are common and conserved in the mosquito microbiome," PLoS One, vol. 14, no. 8, pp. 1-16, 2019.

[10] S. O. Dapaah, C. Agyare, Y. D. Boakye, and T. Appiah, "Modulatory effects of Hilleria latifolia and Laportea ovalifolia on activity of selected antibiotics," Journal of Medicinal Plants Research, vol. 10, pp. 360-366, 2016.

[11] J. K. Adu, K. Twum, A. Brobbey, C. D. K. Amengor, and Y. Duah-Boakye, "Resistance modulation studies of vernolide from Vernonia colorata (Drake) on ciprofloxacin, amoxicillin, tetracycline and erythromycin," The Journal of Phytopharmacology, vol. 7, no. 5, pp. 425-430, 2018.

[12] E. A. Dikusar and V. I. Potkin, "Synthesis and properties of substituted benzaldehyde phenylhydrazones," Russian Journal of General Chemistry, vol. 79, no. 5, pp. 781-784, 2009.

[13] A. Rahmat, M. Akranth, A. Tauquir et al., "Review of biological activity of hydrazone," Indonesian Journal of Pharmacy, vol. 23, no. 4, pp. 193-202, 2012.

[14] R. Karnawat, S. Ginni, I. K. Sharma, and P. S. Verma, "Synthesis, characterisation and antimicrobial screening of some azo compounds," International Journal of Applied Biology and Pharmaceutical Technology, vol. 2, pp. 332-338, 2011.

[15] M. Asif and A. Husain, "Analgesic, anti-inflammatory, and antiplatelet profile of hydrazones containing synthetic molecules," Journal of Applied Chemistry, vol. 2013, Article ID 247203, 7 pages, 2013.

[16] A. Kajal, S. Bala, N. Sharma, S. Kamboj, and V. Saini, "Therapeutic potential of hydrazones as anti-inflammatory agents," International Journal of Medicinal Chemistry, vol. 2014, Article ID 761030, 11 pages, 2014.

[17] G. Jadon and L. Kumawat, "Synthesis, spectral and biological evaluation of some phenyl acetic acid hydrazone derivatives," International Journal of Pharmaceutical Sciences and Research, vol. 2, pp. 2408-2412, 2011.

[18] P. Oliveira, B. Guidetti, A. Chamayou et al., "Mechanochemical synthesis and biological evaluation of novel isoniazid derivatives with potent antitubercular activity," Molecules, vol. 22, no. 9, 2017.

[19] T. Govindasami, A. Pandey, N. Palanivelu, and A. Pandey, "Synthesis, characterization and antibacterial activity of biologically important vanillin related hydrazone derivatives,"
International Journal of Organic Chemistry, vol. 1, no. 3, pp. 71-77, 2011.

[20] K. Kiran, D. Ashok, B. A. Rao, M. Sarasija, and A. S. Rao, "Synthesis, characterisation, and antibacterial activity of some novel vanillin related hydrazone derivatives bearing 1, 2, 3triazole ring," Russian Journal of General Chemistry, vol. 87, no. 6, pp. 1288-1294, 2017.

[21] S. S. Kadam, S. T. Tambe, N. D. Grampurohit, and D. D. Gaikwad, "Review article on chemical importance of Brady's reagent," International Journal of Research in Pharmacy and Chemistry, vol. 2, no. 4, pp. 1086-1092, 2012.

[22] C. Agyare, J. Antwi Apen, F. Adu, E. Kesseih, and Y. Duah Boaky, "Antimicrobial, antibiotic resistance modulation and cytotoxicity studies of different extracts of Pupalia lappacea," Pharmacologia, vol. 6, no. 6, pp. 244-257, 2015.

[23] F. Adu, S. Gbedema, and K. Annan, "Antimicrobial and resistance modulatory activities of Corynanthe pachyceras," Pharmacognosy Research, vol. 1, no. 5, pp. 280-284, 2009.

[24] J. M. Andrews, "Determination of minimum inhibitory concentrations," Journal of Antimicrobial Chemotherapy, vol. 48, no. 1, pp. 5-16, 2001.

[25] D. L. Pavia, G. M. Lampman, G. S. Kriz, and J. R. Vyvyan, "Infrared spectroscopy," Introduction to Spectroscopy, vol. 3, pp. 380-383, 3rd edition, 2001.

[26] A. A. Olaniyi, Principles of Drug Quality Assurance and Pharmaceutical Analysis, Mosuro Publishers, Ibadan, Nigeria, 2000.

[27] A. T. Al-Thib and N. A. Khudhair, "Spectroscopic study of some aromatic hydrazones derivated from aromatic substituted benzophenone and benzaldehyde," Physical Chemistry an Indian Journal, vol. 11, no. 1, pp. 25-34, 2016.

[28] L. G. Alves, P. F. Pinheiro, J. R. Feliciano Dâmaso, D. P. Leitão, and A. M. Martins, "Synthesis, antimicrobial activity and toxicity to nematodes of cyclam derivatives," International Journal of Antimicrobial Agents, vol. 49, pp. 646-649, 2017. 